\title{
WRITING AS LIVING COMPOS(T)ING: POETRY AND DESIRE
}

\author{
by \\ Carl Leggo \\ Department of Language and Literacy Education \\ University of British Columbia \\ Vancouver, BC
}

\begin{abstract}
I will not tell you or sell you a line. As a punishment in elementary school, my teacher required me to write lines, and for years, all my writing was linear, a composition of lines that began at the left edge of the page and marched with hypnotic fervour to the right edge of the page, a composition of lines that began at the top of the page and wound with galvanized zeal to the bottom of the page, a composition of lines that began at the beginning of the book and plodded with mesmerized devotion to the end of the book, a composition of lines that began at the beginning of September and snaked with soporific steadfastness

to summer's respite. But in my linear writing I lived a lie, a fabrication tailored from a fabric of neat geometric lines angles corners planes

founded on axioms theorems and precise measures of consistency, convention, comprehension, conciseness, co-ordination, correctness, and conclusion.
\end{abstract}




\title{
WRITING AS LIVING COMPOS(T)ING: POETRY AND DESIRE
}

\author{
by \\ Carl Leggo \\ Department of Language and Literacy Education \\ University of British Columbia \\ Vancouver, BC
}

A poet stands before reality that is every day new, miraculously complex, inexhaustible, and tries to enclose as much of it as possible in words. (Milosz 56)

All the questions I need to ask; the stories I have yet to hear. The heart's two chamberseverything I most desire, everything I most fear. (Keefer 291)

To be a poet in a destitute time means: to attend, singing, to the trace of the fugitive gods. This is why the poet in the time of the world's night utters the holy. (Heidegger 94)

I will not tell you or sell you a line. As a punishment in elementary school, my teacher required me to write lines, and for years, all my writing was linear, a composition of lines that began at the left edge of the page and marched with hypnotic fervour to the right edge of the page, a composition of lines that began at the top of the page and wound with galvanized zeal to the bottom of the page, a composition of lines that began at the beginning of the book and plodded with mesmerized devotion

to the end of the book, a composition of lines that began at the beginning of September and snaked with soporific steadfastness to summer's respite. But in my linear writing I lived a lie, a fabrication tailored from a fabric of neat geometric lines angles corners planes

founded on axioms theorems and precise measures of consistency, 
convention, comprehension, conciseness, co-ordination, correctness, and conclusion.

\section{Now I know my writing \\ is no linear composition; \\ it is a living composting.}

bell hooks writes: "like desire, language disrupts, refuses to be contained within boundaries. It speaks itself against our will, in words and thoughts that intrude, even violate the most private spaces of mind and body" (167).

Because we are constituted in language, because we know ourselves in language, because we constantly write ourselves, and rewrite ourselves, and write our relations to others, and seek to understand

the loneliness alienation separateness we know always, we need frequent opportunities to engage in discursive practices,

and an environment which nurtures desire, insatiable desire, to know, to quest/ion, to seek.

So, I explore ways of writing that expose lies like vermilion threads tangled in the illusion of a linear composition that composes lives as lines by experimenting with composing in poetry, posing in poetry, seeking composure and repose without imposing, always afraid of disposing and decomposing, constantly proposing and supposing the fecundity of composting.

\section{COYOTE WRITING}

I leaned in the coulee long enough to learn the coulee's flow in me, walked narrow trails, traces of other lines, written to and fro, when a coyote 
composed its own line across the coulee's wall turned at the ridge

looked back to see

if I was chasing her, knowing I was

and was not, slipped over the edge:

where does the coyote go?

Betsy Warland writes: "i believe writing we value is writing which springs from necessity. the necessity to speak the unspoken, the taboo of our lives. if we do not, we BETRAY: 'trans-, over + dare, to give' ourselves over, turn ourselves in, become agents of our own absence" (60).

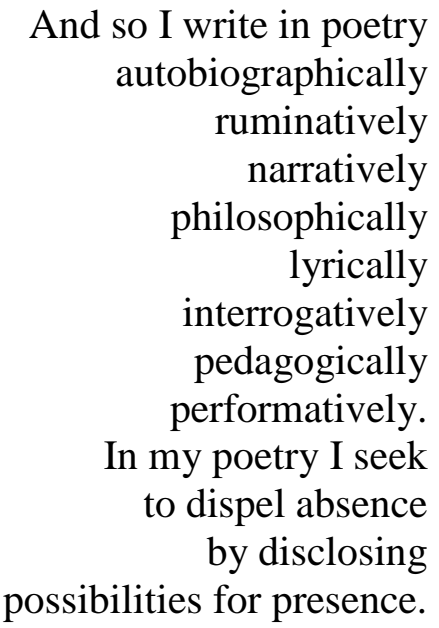

\begin{abstract}
Now I know my writing is no linear composition; it is a living composting.
\end{abstract}

\title{
MOCCASINS
}

with the honorarium

from my first published poems

I bought a pair of moccasins

in the Fredericton farmer's market

ordered exactly what I wanted:

soft deerskin leather, ankle high, a rubber sole for walking, and beads (men's moccasins ordinarily didn't have beads)

they fit like a word that gives you goose-bumps 
I only wore them when I wrote poems

or thought about writing poems

or felt like a poem

the rubber heel was replaced a few times

they were sewed a few times

the leather lace was replaced a few times

some of the beads fell off

after years I only wore them

once or twice a year,

storing the poetry in my blood

like a winter stone in November sun

so she knew what she was doing

when she slashed them

with an exacto knife

and left them in the closet

where I would find them

after she was gone

it has taken a long time to write this poem

Ursula A. Kelly writes: "Seizing the importance of re-presenting and re-writing our selves as we reconstruct our visions of world communities entails deconstructing the stories we tell (of) ourselves and the desires that inform them" (49).

One Father's Day a while ago my son and I went to the carnival where he invited me to climb a rock wall, and strapped into harness and ropes, I fearfully approached the wall, several stories high, until I saw the finger and toe holds were letters of the alphabet and then zig-zagged into the June sky knowing once more the universe is no single verse, no unified verse.

\section{DIARIES}

all her adolescent/adult life

my friend's mother kept a diary, scribbled blank pages

bound in black and burgundy leather, 
a store of words in an attic

bookcase, always locked

on her seventieth birthday

my friend's mother drank tea

under a bare birch tree,

watched the autumn leaves burn,

and wrote in her diary,

The End,

then gathered up her black

and burgundy years of words,

several boxes full,

carried them to the front yard

like a pallbearer and burned them,

month by month, with the leaves

my friend asked why;

his mother replied,

When I'm gone I don't want

you to read them and think,

All her life

my mother was mad

Martin Heidegger writes: "Truth, as the clearing and concealing of what is, happens in being composed, as a poet composes a poem. All art, as the letting happen of the advent of the truth of what is, is, as such, essentially poetry. The nature of art, on which both the art work and the artist depend, is the setting-itself-into-work of truth. It is due to art's poetic nature that, in the midst of what is, art breaks open an open place, in whose openness everything is other than usual" (72).

Now I know my writing

is no linear composition;

it is a living composting.

\section{THE OL’ KEG PUB}

in the Ol' Keg Pub in Kitimat

the server asked me, what

are you writing perhaps

threatened by my writing

in a journal like I am writing

about her, will reveal

her secrets or do we fear

voyeurs, the whole universe,

everyone watching 
and watched or perhaps

we hope others are writing

us, always hoping beyond

hope for any sign of attention

when the server asked

what I was writing,

I told her, I'm a poet and professor

like that explained something

when I should have said,

like Hamlet, Words, words,

or even a poem for making sense

of the snowstorm aswirl in my head

and heart, instead I declared

my credentials as if that

was somehow important,

as if my labels defined

who I am or might claim

attention in the Ol' Keg Pub in Kitimat.

or I should have said,

I am writing about

Lana who blesses me

with a long love weathered

by tempestuous winds

battered by tempests,

no tempest in a teapot

or I should have said nothing,

just scribbles that hold me a little while

so when Tina stops by,

drunk, of course, and speaks

about sadness, psychology, parenthood

I can listen, even hear her

Michel Foucault writes: "When language arrives at its own edge, what it finds is not a positivity that contradicts it, but the void that will efface it. Into that void it must go, consenting to come undone in the rumbling, in the immediate negation of what it says, in a silence that is not the intimacy of a secret but a pure outside where words endlessly unravel" (22).

The poems

are an act:

look and see, smell and remember, 
touch and feel, taste and savour hear and listen.

The poems are not in the letters of all the alphabets of all the languages of all the words in all the worlds in all the multiverse.

The poems are not in the landscape mindscape heartscape escape.

The poems are breath, breaths of long desire without end.

\author{
Now I know my writing \\ is no linear composition; \\ it is a living composting.
}

John Steffler writes: "poetry approximates, through the powerful use of language, our fundamental, original sense of life's miraculousness, its profound and mysterious meaning" (47)

\title{
FRAGMENTS
}

\section{1}

on his seventy-first birthday

Skipper said,

I'm a depression baby

but I'm not depressed

2

I went to a counsellor and she walked with me through the tangled garden of almost five decades of living in the earth to a quiet meadow where my father and I stood all alone among the dandelions, 
both dazed and lost

3

a man met Jesus in the market-place

and asked, When are you going to return?

4

one summer I worked at the mill

and dug a clean clear hole

in a single afternoon

but the foreman said my hole

made the other workers look lazy,

so I dug a second hole, slow and sloppy,

like a delinquent gopher,

in days without end

5

I don't want to be a soap box evangelist

preaching damnation

or a late night show host writing

the world a bigger joke

or a car salesman promising a Land Rover

will help me wend my way

through an urban maze of rhinoceroses

what is the poet's place?

6

my dentist scrapes and grinds

my teeth and regales me

with stories of her belly dancing

7

I thought I was in love, wildly in love,

but really I was just

a chunk of knotted alder

turned on a lathe

spinning sharp shaped

by a tungsten blade

like a kiss 


\author{
I became \\ a decorative spindle \\ without edges \\ a kind of swindle
}

8

she wanted me to look after her

I wanted her to look after me:

stalemate, even stale mates,

after a while, KFC on Loonie Tuesdays

and beer and chicken fingers

in King's Head Inn on the patio

in the easy bake oven sun

where the stairs climbed only

to the washroom, no heaven

9

I always hope wisdom can be contained in fridge magnets

like Carrie's wisdom:

always remember to forget

what you don't know won't hurt you

always remember somebody nice

kindness somehow stays with you

be open to new ideas

we're getting older like everybody else

be nice to want nothing

everything is good

10

she told me she had lived for a time with an older lover but the chemistry spoiled when they disagreed about a new sofa 
three sisters went to a fourth sister's funeral

and on their way home on the highway

that winds along the Great Northern Peninsula

crashed into a pick-up driven by a drunk

\section{2}

Billy Mercer told Carrie,

I don't want any flowers

strewn over my grave

when I'm gone,

but Skipper has strewn

a lot of flowers

around me while I'm here

\section{3}

as a boy Carrie always bought me

McGregor Happy Foot socks, soft and comfortable, recently I bought myself a pair, already I feel happier

\section{4}

one summer Scotties chips

sponsored a contest,

facsimiles could be redeemed

for Whitman classics,

Tom Sawyer and Robinson Crusoe,

I ate a lot of chips that summer

Now I know my writing

is no linear composition;

it is a living composting.

Don McKay writes: "Poets are supremely interested in what language can't do; in order to gesture outside, they use language in a way that flirts with its destruction" (27).

In school I was drilled in grammar exercises till I could only march straight ahead or turn right and left. 
My writing was the progeny, no prodigy, of intercourse with conventions and rules and the teacher's red pencil, of intercourse without desire, but creeping to middle age I heard voices calling desire, and learned writers full of desire who write with desire will write desire in writing full of desire.

Attending to writing both attenuates and exhilarates, overwhelms with desire, desire to shape and control words, desire to disclose the world in words, desire to be shaped and controlled by words, desire to be disclosed in words. But for all the desire in writing, the consummation is never total.

\section{WAILING WITH ROY ORBISON}

the highway between Morrow's Cove and Corner Brook is three hundred miles of ice with twists and turns in limestone hills around frozen ponds etched in dense spruce, a desolate winterland where I drive a pencil scribble with Roy Orbison wailing, Only the lonely know the way I feel tonight

but even Roy has never met Caitlin, who after seven silent years summoned me to the lounge of Gaudot's Hotel where I longed for a priest's clean word; I wanted Caitlin to declare absolution, and she said absolutely nothing, just stared with the sanitary blue that turns your heart into quartz

one summer evening in another world with other words, Caitlin and I walked the beach of Black Bank and talked poetry, when in the dusk she slipped away, always 
slipping away with wry little smiles over her shoulder like Meryl Streep

in French Lieutenant's Woman, a text that compelled and defied me,

I waited and waited till she screamed

like lightning, and found her in tall grass

giggling like a gaggle of geese,

I knew you would come, I knew she knew,

I always answered because I wanted

to save Caitlin, to destroy the monsters

I pretended held her imagination,

but Caitlin didn't really need me,

the only self-contained person

I've ever known: she knew her heart, to write the world in her image,

a desert winter land where the end

is never written, only kept in play

like a ball that mustn't touch the ground,

and I was mesmerized, but now

in the winter night of a new moon

I write this poem, and if I can

navigate the icy highway all the way

home, I will continue to write it,

so when Caitlin screams again

I won't hear her, filled with my poem

and Roy Orbison's wailing, Only

the lonely know the way I feel tonight,

better than I've felt in a long long time

In words I write my worlds, aware always I cannot get it right, aware only I do not know what it is.

Even now as I write, I ask, Who will understand these words?

Who will stand with desire long enough to know these words? Writing is overwhelming with desire, the desire to know my world in words,

the desire to know others knowing other worlds in other words fired by desire without end. 
is no linear composition;

it is a living composting.

\section{Works Cited}

Foucault, Michel. Maurice Blanchot: The Thought from Outside. Trans. Brian Massumi. New York: Zone Books, 1990.

Heidegger, Martin. Poetry, Language, Thought. Trans. Albert Hofstadter. New York: Harper and Row, 1971.

hooks, bell. Teaching to Transgress: Education as the Practice of Freedom. New York: Routledge, 1994.

Keefer, Janice Kulyk. Honey and Ashes: A Story of Family. Toronto: HarperCollins, 1998.

Kelly, Ursula A. Schooling Desire: Literacy, Cultural Politics, and Pedagogy. New York: Routledge, 1997.

McKay, Don. "Baler Twine: Thoughts on Ravens, Home, and Nature Poetry." Tim Lilburn, ed. Poetry and Knowing: Speculative Essays and Interviews. Kingston: Quarry Press, 1995. 17-28.

Milosz, Czeslaw. The Witness of Poetry. Cambridge: Harvard UP, 1983.

Steffler, John. "Language as Matter." Lilburn, Tim, ed. Poetry and Knowing: Speculative Essays and Interviews. Kingston: Quarry Press, 1995. 45-51.

Warland, Betsy. Proper Deafinitions: Collected Theorograms. Vancouver: Press Gang Publishers, 1990. 